\section{THE LANCASHIRE SEA FISHERIES LABORATORY.}

'THE twenty-first annual report of this laboratory contains an interesting record of the routine work and investigations carried on during IgI2. The usual four classes for fishermen were held at Piel during the spring; fifty-two fishermen received instruction in marine biology, with special reference to the life-history and habits of fishes and the more common invertebrates captured in the trawl-net, and thirty-nine of the men attended also the course in navigation.

Mr. Johnstone continues his records of diseased conditions of fishes. He describes and figures a fibromatous tumour from a halibut, melanotic sarcomata in skate, and tubercular lesions in a cod. Piscine tubercle has been known hitherto only in freshwater fishes, and it is therefore of interest to find the present typical lesions in a fish living in the open and not likely to have become infected by landdrainage. Dr. Alexander contributes a review of piscine tubercle, and gives a description of an acidfast bacillus found in the cod above-mentioned. The lesions were skin infections, resembling lupus, and containing typical tubercles. The organism was found to be non-pathogenic for the guinea-pig.

Mr. Johnstone gives a detailed report on the more important mussel-beds in Lancashire and North Wales in regard to their liability to sewage contamination. His investigations show that the mussels from certain areas, e.g. parts of the Conway and Lune estuaries, are objectionable as articles of food, and he urges the necessity for supervision of natural shellfish beds, in the interests not only of public health, but of the shellfish industry.

In his account of the measurements and variations in the condition of plaice, Mr. Johnstone suggests that the main cause of the periodic migrations made by plaice is change of temperature. The migration is of the nature of an adaptation to a change in the environment, the plaice responding by so moving that the temperature-change becomes minimal.

Mr. Riddell gives an account of the plankton collections obtained during IgI2 in the Irish Sea. Prof. Bassett, in reporting on the water samples taken at the same time, points out that very high salinities prevailed throughout the year I9I2, especially at certain stations on the line from Holyhead to the Calf of Man, due to the flooding of the English Channel and Irish Sea by water of Mediterranean origin. He briefly discusses the types of oceanic circulation in the North Atlantic, and concludes that there are corresponding meteorological conditions, and that the latter, in so far as they affect the succeeding summer, can be foreseen from the value and time of occurrence of the maximum salinities in the Irish Sea.

The intensive study of the plankton around the south end of the Isle of Man has been continued. The maxima of the diatoms and most other plankton groups were earlier in ror 2 than I9II. Examination of the various forms of the diatom Biddulphia leads Prof. Herdman and his collaborators to regard $B$. sinensis and $B$. regia as two forms of the original species B. mobiliensis. Mr. Scott reports on the pelagic fish-eggs of this area, and $\mathrm{Mr}$ Jackson on the decapod larvæ.

Prof. Herdman and Mr. Riddell, in their report on the plankton of the west coast of Scotland, state that the phytoplankton, which was so widespread in July, roog and roIr, especially round Mull, seems in the last two summers, and particularly in August, I9I2, to have become pushed back or restricted to the more land-locked waters by an unusual influx of characteristically oceanic organisms from the Atlantic, e.g. the copepods Metridia lucens and Candacia armata. It is suggested that in the Hebrides there is a definite connection between the presence of oceanic water containing the copepod Calanus in quantity and shoals of herrings, for large hauls of Calanus were, on several occasions, obtained at places where, either the night before or the night after, good catches of herrings were reported.

\section{BRITISH FORESTRY.1}

THE useful publication before us (though foresters have to mourn the death of its long-time editor) retains its high standard of excellence. At the annual general meeting of the society, instead of a formal address there was a discussion on the relation of forestry to agriculture, \&c. It is sufficient to follow this discussion to see what a strong body of opinion exists amongst practical men-forest owners and foresters-in favour of a comprehensive scheme of national forestry. The conclusions arrived at in this discussion vary little from those expressed in the Coast Erosion report of 1908 , and in the similar Committee reports that preceded it.

The average rental of hill grazing ground suitable for forest planting in the north-east of Scotland is not more than Is. per acre. This fact opens up a great national question of the more profitable use of the land in these islands, which are themselves one of the most fertile and productive countries of the world. Then there is the question of small holdings. These are linked with forestry in the sense that they cannot generally exist under present conditions without the help afforded from winter labour in the forest. Looked at from a national point of view, the labour question means, in the case of grazing and shooting, two or three men employed per rooo acres, against about Ios. per acre per year wages in forestry. The careful Prussian statistics give II $s$. $4 d$. per acre per year as the average forest wages bill. About one man to fifteen is the grazing-versus-forest ratio given in the Coast Erosion Committee's report.

This rural labour, priceless from a national wellbeing point of view, is being lost to the country, and some $30,000,000 l$. is being sent out of the country yearly for timber and forest products which might be produced in these islands.

Says Mr. Munro Ferguson, commenting on the last forest Blue-book (Rept. of Advisory Com. on Forestry, Cd. 6713):- "While the Administration gropes its way in the dark, and while the paramount national interest of silviculture (as affording the widest scope for additional skilled labour on the land) is neglected, 3000 emigrants leave the Clyde weekly." Mr. Munro Ferguson was the first large forest owner in Scotland to bring his own woodlands under scientific management, and he has since then represented forestry in almost every capacity.

The full text is given of the address of Sir John Sterling Maxwell (the retiring president of the Royal Scottish Arboricultural Society) to the Aberdeen branch. This was summarised in the April number of the Quarterly Journal of the English Arboricultural Society. It may be looked on as the most important pronouncement, in favour of a comprehensive scheme of State forestry, that has yet been made by an influential owner of forests in these islands: It is well termed, "The Place of Forestry in the Economic Development of Scotland." No lover of trees, no one

1 Trancactions of the Roval Scottish Arhoricultural Society, vol, xxvii. part ii., July, ror3. (Edinburgh : Douglas and Foulis.) 